\title{
EFEKTIVITAS PEER EDUCATION COVID-19 TERHADAP TINGKAT KECEMASAN PADA PASIEN LANSIA YANG MENGALAMI DIABETES MELLITUS
}

\author{
Dewi Wijayanti \\ Prodi DIII Keperawatan Universitas Borneo Tarakan \\ *Email: dewi.wijayanti8386@gmail.com
}

\begin{abstract}
Abstrak
Wabah Covid-19 berdampak pada psikis seseorang, termasuk lansia yang mengalami komplikasi penyakit tertentu sangat rentan terpapar virus tersebut. Education merupakan sumber informasi yang dapat membantu pasien diabetes mellitus dalam mengambil keputusan tindakan keperawatan mandiri yang tepat, namun lansia yang dirawat di panti werdha sangat minim akan informasi kesehatan. Tujuan Penelitian : Menganalisis efektivitas Peer Education Covid-19 Terhadap Tingkat Kecemasan Pada Lansia Yang Mengalami Diabetes Mellitus Di Panti Werdha Al-Marhamah Tarakan Kalimantan Utara. Metode penelitian : Penelitian ini merupakan penelitian kuantitatif, dengan desain penelitian quasi experiment pretest and post-test control group design. Sampel dalam penelitian ini berjumlah 22 responden, Teknik pengambilan sampel dalam penelitian ini menggunakan teknik purposive sampling. Analisa data menggunakan analisis univariat dan bivariat dengan menggunakan uji wilcoxon. Hasil Penelitian : Terdapat pengaruh efektivitas yang bermakna terhadap tingkat kecemasan pada pasien lansia yang menderita diabetes mellitus di panti werdha Al-Marhamah Tarakan Kalimantan Utara. saran : Tenaga pelayanan kesehatan dapat meningkatkan upaya promotif dan preventif, sosialisasi edukasi untuk meningkatkan informasi kesehatan pada lansia .
\end{abstract}

Kata Kunci : Education, covid-19, Diabetes Mellitus dan Kecemasan

\begin{abstract}
The Effectiveness of Peer Education Covid-19 on Anxiety Levels in Elderly Patients with Diabetes Mellitus. The Covid19 outbreak has an impact on a person's physical condition, including the elderly who experience complications of certain diseases and are very vulnerable to being exposed to the virus. Education is a source of information that can help diabetes mellitus patients in making the right independent nursing action decisions, but the elderly who are cared for in nursing homes have very little health information. Aims: Analyzing the effectiveness of Covid-19 Peer Education on Anxiety Levels in the Elderly with Diabetes Mellitus at the Al-Marhamah Nursing Home in Tarakan, North Kalimantan. Method: This research is a quantitative study, with a quasi-experimental research design pre-test and post-test control group design. The sample in this study amounted to 44 respondents, the sampling technique in this study using purposive sampling technique. Analysis used univariate and bivariate analysis by using the wilcoxon test. Result: There is a significant effect of effectiveness on the level of anxiety in elderly patients suffering from diabetes mellitus in the Al-Marhamah Tarakan nursing home, North Kalimantan. Suggestion: Health service personnel can increase promotional and preventive efforts, disseminate education to improve health information for the elderly
\end{abstract}

Keywords: Education, covid-19, Diabetes Mellitus and Anxiety. 


\section{Pendahuluan}

Covid-19 berawal ditemukan di wilayah Wuhan China pada tahun 2019, yang menjadi problematik sehingga mengganggu aspek kehidupan sosial masyarakat di seluruh Indonesia, hal ini berdampak pada kesehatan masyarakat Indonesia yang sangat mengkhawatirkan, terhambatnya proses di semua bidang seperti ekonomi, pendidikan, dan pelayanan public. Covid-19 mampu menggoyahkan kepanikan, kecemasan pada orang yang rentan dan beresiko tinggi terpapar virus ini seperti pada lanjut usia (Lansia) dan pasien yang memiliki riwayat penyakit penyerta. Pasien lansia dengan penyakit penyerta seperti lansia dengan diabetes mellitus (DM) beresiko tinggi mengalami penurunan kesehatan dan beresiko tinggi terpapar covid-19 (Alodokter, 2020).

Proses menua adalah suatu proses alami yang akan terjadi pada setiap makhluk hidup, diawali dengan proses kelahiran, dewasa, berkembang biak, menjadi tua hingga, tutup usia(Suardiman, 2011). Proses penuaan berdampak pada berbagai aspek kehidupan, baik sosial, ekonomi maupun kesehatan. Secara sosial, kehidupan lansia sering dipersepsikan negatif seperti lansia dianggap sebagai beban hidup. Secara ekonomi, umumnya lansia lebih dipandang sebagai beban dari pada potensi sumber daya bagi pembangunan. Lansia dianggap sebagai warga yang tidak produktif dan hidupnya bergantung pada keluarga atau generasi muda. Secara kesehatan, diketahui semakin bertambah usia maka lansia lebih rentan terhadap berbagai penyakit, keluhan fisik, baik karena faktor alamiah seperti disebabkan karena daya tahan fisik maupun penyakit (Infodatin, 2014).

Penelitian yang dilakukan oleh (Khasanah \& Khairani, 2016), tentang tingkat kecemasan pada lansia yang mengalami penyakit kronis di Banda Aceh, didapatkan $50 \%$ responden yang mengalami kecemasan berada pada usia 60-74 tahun. Berdasarkan (Geier, 2011), usia di atas 65 tahun sangat rentan terhadap sejumlah penyakit fisik dan psikologis sehingga sering memicu gangguan kejiwaan.

Keluhan kesehatan lansia yang paling tinggi adalah keluhan yang merupakan golongan penyakit tidak menular, kronik dan generatif (Rochman, 2006). Pendapat (Stanhope M \& Lancaster, 2004) yang menyatakan bahwa lansia termasuk suatu kelompok rentan yang lebih mudah untuk mengalami masalah kesehatan sebagai akibat terpajan resiko atau akibat buruk dari masalah kesehatan, dimana salah satu masalah kesehatan yang berkaitan dengan bertambah usia yaitu diabetes mellitus.

Diabetes Mellitus (DM) merupakan kelompok penyakit metabolik dengan 
karakteristik hiperglikemia yang terjadi karena adanya gangguan metabolisme karbohidrat, lemak dan protein, sehingga mengakibatkan kelainan sekresi insulin dan kerja insulin atau kedua-duanya (ADA, 2010). Data yang didapat di Indonesia bahwa lansia pada umumnya menderita penyakit diabetes mellitus dimana penyakit diabetes mellitus masuk dalam 10 besar penyakit dan diabetes mellitus menempati ranking 5 penyakit yang paling sering dialami oleh lansia. Dampak dari berbagai penyakit tersebut akan mempengaruhi kehidupan lansia yang umumnya dapat menyebabkan penurunan kesejahteraan, mengancam kemandirian lansia bahkan mengancam jiwa(El-Gabalawy, R, 2014).

Permasalahan psikologis yang sering dialami oleh lansia meliputi kecemasan, ketakutan, mudah tersinggung, rasa kesepian hingga hilangnya rasa percaya diri. Kecemasan yang dialami oleh lansia disebabkan oleh perasaan cemas akan hal-hal yang tidak diketahuinya, kecemasan akan penyakit, cemas akan tersingkirkan dari kehidupan sosial, cemas terhadap perubahan fisik, cemas perubahan anggota tubuh bahkan kecemasan akan kematian. Dampak kecemasan yang dialami oleh lansia meliputi terjadinya penurunan aktivitas fisik dan status fungsional, persepsi diri tentang kesehatan yang tidak baik, menurunnya kepuasan hidup (life satisfaction) dan kualitas hidup (quality of life), meningkatnya kesepian (loneliness) dan penggunaan pelayanan serta menghabiskan biaya yang besar untuk pelayanan (Tampi, 2014).

Kecemasan yang dialami oleh lansia di panti werdha Al-marhamah Tarakan Kalimantan Utara di masa pandemic covid-19 karena lansia tidak terpapar dengan sumber informasi tentang penyakit dan kesehatan saat ini. Ketersediaan sumber informasi yang minim, keterbatasan fisik karena faktor usia, sulit belajar, riwayat penyakit penyerta yang diderita lansia berkontribusi terhadap masalah kesehatan. Pendidikan kesehatan merupakan salah satu faktor dasar yang dapat mengkondisikan seseorang untuk dapat meningkatkan kemampuan diri, meningkatkan pengetahuan, keterampilan dan sikap diri mereka (Perkeni, 2011).

Proses pemahaman lansia dengan DM, ini terjadi melalui pendidikan kesehatan, dengan memberikan informasi sehingga akan timbul kesadaran pada individu atau masyarakat untuk berperilaku sesuai dengan pengetahuan yang dimilikinya, edukasi diberikan dengan tujuan agar informasi tentang penyakit tersampaikan dengan benar dan tepat pada lansia, sehingga lansia dapat merasakan bahwa dirinya lebih sehat. Pasien lansia dengan penyakit penyerta seperti lansia dengan diabetes mellitus (DM) yang dirawat di panti 
werdha Al-Marhamah beresiko tinggi mengalami penurunan kesehatan dan beresiko tinggi terpapar covid-19.

\section{Metode}

Penelitian ini merupakan penelitian kuantitatif, dengan desain penelitian quasi experiment pre-test and post-test control group design, yaitu peneliti menganalisis dan membandingkan efektivitas peer education tentang covid-19 terhadap tingkat kecemasan pada lansia yang mengalami diabetes mellitus pada kelompok intervensi dan kelompok kontrol.

Teknik pengambilan sampel dalam penelitian ini menggunakan teknik purposive sampling, yaitu teknik penentuan sampel dengan pertimbangan tertentu sesuai dengan kriteria inklusi yang ditetapkan oleh peneliti (Sugiyono, 2006). Kriteria inklusi dalam penelitian ini adalah lansia yang menderita penyakit DM dan bersedia menjadi responden, lansia yang aktif dan kooperatif, lansia yang tidak mengalami penurunan kesehatan dan lansia yang mampu berkomunikasi dengan baik. Penelitian dilakukan di panti werdha AlMarhamah Tarakan Kalimantan Utara, dimulai dari bulan Juli sampai dengan Agustus 2020 dengan jumlah sampel sebanyak 22 responden. Pengumpulan data dalam penelitian ini menggunakan kuesioner Hamilton Rating Scale for Anxiety (HRS-A) yang baku dan uji statistic menggunakan Wilcoxon.

\section{Hasil}

Penelitian ini dilakukan pada 22 responden merupakan pasien lansia yang menderita penyakit DM, aktif dan kooperatif, lansia yang tidak mengalami penurunan kesehatan, dan lansia yang mampu berkomunikasi dengan baik, yang berada di panti werdha al Marhamah Tarakan Kalimantan Utara.

Tabel 1 Tingkat Kecemasan Responden Sebelum Intervensi $(n=22)$

\begin{tabular}{lcccc}
\hline Kelompok & $\begin{array}{c}\text { Kecemasan } \\
\text { Ringan }\end{array}$ & $\begin{array}{c}\text { Kecemasan } \\
\text { Sedang }\end{array}$ & Kecemasan Berat & $\begin{array}{c}\text { Kecemasan } \\
\text { Sangat Berat }\end{array}$ \\
\hline Intervensi & $1(9 \%)$ & $3(27 \%)$ & $6(55 \%)$ & $1(9 \%)$ \\
\hline Kontrol & $1(9 \%)$ & $4(36 \%)$ & $5(46 \%)$ & $1(9 \%)$
\end{tabular}

Tabel 1 Menunjukkan bahwa pada kelompok intervensi, responden yang memiliki tingkat kecemasan berat sebanyak 6 orang (55\%). 
Tabel 2 Tingkat Kecemasan Pada Responden Setelah dilakukan Intervensi educasi $(n=22)$

\begin{tabular}{lcccc}
\hline Kelompok & $\begin{array}{c}\text { Kecemasan } \\
\text { Ringan }\end{array}$ & $\begin{array}{c}\text { Kecemasan } \\
\text { Sedang }\end{array}$ & Kecemasan Berat & $\begin{array}{c}\text { Kecemasan } \\
\text { Sangat Berat }\end{array}$ \\
\hline Intervensi & $9(82 \%)$ & $2(18 \%)$ & $0(0 \%)$ & $0(0 \%)$ \\
\hline Kontrol & $1(9 \%)$ & $4(36 \%)$ & $5(46 \%)$ & $1(9 \%)$ \\
\hline
\end{tabular}

Tabel 2.2. Menunjukkan bahwa pada kelompok intervensi setelah diberikan perlakuan berupa edukasi tentang covid-19 didapatkan hasil, responden yang memiliki tingkat kecemasan ringan sebanyak 9 orang $(82 \%)$ dan kelompok kontrol didapatkan hasil kecemasan berat sebanyak 5 orang (46\%).

Tabel 3 Efektivitas Peer Education Tentang covid-19

Terhadap Tingkat kecemasan Lansia yang mengalami DM (n=22)

\begin{tabular}{cccccccc}
\hline Kelompok & & $\mathrm{N}$ & $\begin{array}{c}\text { Min- } \\
\text { Max }\end{array}$ & Mean & $\begin{array}{c}\text { Mean } \\
\text { Differance }\end{array}$ & SD & $\begin{array}{c}\text { Asymp.sig } \\
(2 \text {-tailled })\end{array}$ \\
\hline Intervensi & Pre & 11 & $16-30$ & 21,50 & & 3,121 & 0,000 \\
\hline \multirow{2}{*}{ Kontrol } & Post & & $22-35$ & 30,69 & $-9,19$ & 2,455 & \\
\hline & Pre & 11 & $15-26$ & 20,81 & $-0,69$ & 2,334 & 0,534 \\
\hline
\end{tabular}

Tabel 3 Menunjukan hasil mean difference sebesar ( -9,19) yang artinya terdapat selisisih peningkatan sebelum dan sesudah dilakukan intervensi sebesar 9,19 dengan nilai $Z$ tabel sebesar $-4,928(-4,928<1,645)$ dan $p$ value $(0,000)$, maka dapat disimpulkan terdapat pengaruh efektivitas yang bermakna pada kelompok intervensi

\section{Pembahasan}

Berdasarkan hasil penelitian didapatkan bahwa edukasi tentang covid-19 pada lansia sangat efektif (82\%) dimana sebelum dilakukan intervensi edukasi didapatkan hasil bahwa lansia di panti werdha memiliki tingkat kecemasan berat sebanyak (55\%). Hal ini sejalan dengan penelitian yang dilakukan oleh (Rafiqa, 2013), tentang gambaran ansietas pada lansia dengan penyakit kronis di Banda Aceh bahwa dari 53 responden, mengalami kecemasan berat $(47,5 \%)$ faktor penyebab adalah kurangnya informasi tentang kesehatan, dukungan keluarga yang tidak optimal dan penurunan fisik akibat penuaan.

Masalah lain yang sering terjadi pada lansia berkaitan dengan penyakit yang diderita lansia adalah kurangnya pengetahuan sehingga berpengaruh pada motivasi dan keputusasaan lansia dalam menghadapi penyakitnya, sehingga menurut teori Health Promotion Model salah satunya adalah perlu diberikan intervensi melalui edukasi (Stanhope, M \& Lancaster, 2004). 
Pasien dengan kondisi penyakit kronis seperti pada pasien diabetes memerlukan suatu sistem pembelajaran yang bersifat kontinu dan terbuka sehingga pasien mampu melakukan self care dengan baik dalam mengelola kecemasan yang dialami, hal ini dibenarkan oleh teori Dorothea orem bahwa seseorang memiliki kemampuan dasar untuk melakukan perawatan terhadap dirinya sendiri dapat mengurangi kecemasan yang dialaminya (Alligood $\mathrm{M}$, 2014). Pasien dengan DM sebenarnya dapat dan mampu melakukan perawatan secara mandiri, hanya saja mereka memiliki keterbatasan dalam perawatan tersebut seperti keterbatasan informasi, sehingga tenaga kesehatan memiliki tanggung jawab untuk memberikan edukasi pada pasien DM sehingga berdampak pada minimal kejadian komplikasi. Hal tersebut sesuai dengan teori yang diungkapkan oleh Dorothea Orem bahwa salah satu metode yang digunakan dalam ke 6 metode untuk meningkatkan self care pada pasien adalah dengan cara pemberian edukasi (Kusniawati, 2011).

Pasien DM yang tidak dikelola dengan baik akan meningkatkan resiko terjadinya komplikasi dikarenakan pada pasien DM rentan mengalami komplikasi yang diakibatkan karena terjadi defisiensi insulin atau menurunnya kerja insulin yang tidak adekuat. Komplikasi yang ditimbulkan bersifat akut maupun kronik dimana komplikasi akut terjadi berkaitan dengan peningkatan kadar gula darah secara tiba-tiba, sedangkan komplikasi kronik sering terjadi akibat peningkatan gula darah dalam waktu yang cukup lama(Flora \& Purwanto, 2014). Penanganan pencegahan yang tidak tepat berdampak pada menurunnya umur harapan hidup apabila lansia sering mengalami kecemasan akibat dari kurangnya informasi edukasi yang didapat.

Upaya tindakan perawatan mandiri, pemberian edukasi oleh tenaga kesehatan menurut peneliti sangat dibutuhkan oleh lansia yang menderita DM dengan tujuan sumber informasi yang diterima dapat mengubah perilaku lansia untuk meningkatkan pemahaman pasien akan penyakit DM yang diderita, sehingga dapat meminimalkan terjadinya komplikasi. Perubahan hasil dari edukasi yang didapat oleh pasien baik dalam bentuk pengetahuan dan pemahaman tentang kesehatan terutama dalam menyikapi adanya wabah covid-19 yang diikuti dengan adanya kesadaran positif terhadap kesehatan mandiri, yang akhirnya dapat diterapkan dalam tindakan untuk meminimalkan kecemasan yang dihadapi oleh lansia yang menderita DM di panti werdha al- marhamah Tarakan Kalimantan utara

\section{Kesimpulan}

Setelah dilakukan intervensi mayoritas responden, baik pada kelompok kontrol maupun kelompok intervensi secara statistik 
mengalami peningkatan, dimana kelompok intervensi mengalami peningkatan yang signifikan sedangkan kelompok kontrol mengalami peningkatan yang tidak signifikan. Responden kelompok intervensi didapatkan hasil yang memiliki tingkat kecemasan ringan sebanyak 19 orang $(86 \%)$. Terdapat pengaruh efektivitas yang bermakna. $p$ value $(0,000)$ pada kelompok intervensi, sedangkan pada kelompok kontrol didapatkan hasil perhitungan mean difference sebesar $(-0,69)$ dan $p$ value $(0,534)$ yang artinya tidak terjadi peningkatan dan pengaruh yang bermakna.

\section{Referensi}

American Diabetes Association. (2010). Diabetes

Care. http://www.ncb.nlm.gov//pmc /articles. Diakses tanggal 18 Agustus 2020 jam 10.00 WITA

Alligood M. (2014). Pakar Teori Keperawatan. Jakarta: Elsevier.

Alodokter. (2020). Covid-19 di Indonesia. http://www.alodokter.com/. Diakses tanggal 12 Agustus 2020 jam 17.00 WITA

El-Gabalawy, R, D. (2014). A longitudinal examination of anxiety disorder and physical health conditions in a nationally representative sample of U.S. older adults. Experimental Gerontology.
Flora, R., \& Purwanto, S. (2014). Pelatihan Senam Kaki Pada Penderita Diabetes Komplikasi Diabetes Pada Kaki ( Diabetes Foot ). Unsri.Ac.Id, 7-15.

Geier, L. (2011). Identifying and managing anxiety disorder in older adults. The Journal for Nurse Practitioners. https://doi.org/10.1016/j.nurpra.2011.05.0 $\underline{22}$

Khasanah, U., \& Khairani. (2016). The Anxiety Level In Elderly With Chronic Disease. 18. Universitas Syiah Kuala.

Kusniawati. (2011). Analisis Faktor Yang Berkontribusi Terhadap Self Care Diabetes Pada Klien Diabetes Mellitus Tipe 2 Di Rumah Sakit Umum Tangerang. Universitas Indonesia.

Perkeni. (2011). Konsensus Pengelolaan dan Pencegahan Diabetes Melitus Tipe 2 di Indonesia. $\quad \mathrm{http}: / / \mathrm{www} . p b p a p d i . o r g$. Diakses tanggal 18 Agustus 2020

Rafiqa. (2013). Gambaran ansietas pada lansia dengan hipertensi di Desa Tibang Kecamatan Syiah Kuala Banda Aceh. Universitas Syiah Kuala

Rochman, W. (2006). Diabetes Melitus Pada Usia Lanjut. Pusat penerbit Departemen penyakit dalam FKUI.

Stanhope, M., \& Lancaster, J. (2004). Community \& public health nursing (Sixth edit). St Louis Missouri: Mosby.

Suardiman, S. P. (2011). Psikologi Usia Lanjut. Gajah Mada university Press.

Sugiyono. (2006). Metode Penelitian Administrasi. Bandung: Alfabeta.

Tampi, R. (2014). Anxiety disorders in late life: a comprehensive review. Healthy Aging Research.

https://doi.org/10.12715/har.2014.3.14 